\title{
Induction Conditions and Kinetic Properties of Quinoline Biodegradation by a Newly Isolated Bacterial Strain
}

\author{
Yu Liu', ${ }^{1,}$ Yongjun Liu' ${ }^{1 *}$, Siyu Hou', Junjun Zhou ${ }^{1}$ \\ ${ }^{1}$ Key Lab of Northwest Water Resources, Ecology and Environment, Ministry of Education, \\ Xi'an University of Architecture and Technology, Xi'an, China \\ ${ }^{2}$ School of Petroleum and Environmental Engineering, Yanan University, Yanan, China
}

Received: 27 June 2018

Accepted: 22 April 2019

\begin{abstract}
In order to strengthen the removal efficiency of heterocyclic nitrogenous compounds in industrial wastewater, a new bacterial strain identified as Bacillus sp. LH-1 was isolated, which could use quinoline as its sole carbon, nitrogen and energy source. The inducing conditions and kinetic properties of quinoline biodegradation by the strain were explored. The results showed that the strain Bacillus sp. LH-1 exhibited maximum tolerance of $700 \mathrm{mgL}^{-1}$ quinoline concentration. After the strain was activated under the conditions of $200 \mathrm{mgL}^{-1}$ quinoline for $120 \mathrm{~h}$, the quinoline degradation was triggered, and the quinoline degradation rate increased approximately 10 times, from $2.030 \mathrm{mg}(\mathrm{L} \cdot \mathrm{h})^{-1}$ to $21.508 \mathrm{mg}(\mathrm{L} \cdot \mathrm{h})^{-1}$. When the initial concentration of quinoline was $300 \mathrm{mgL}^{-1}$, more than $97 \%$ quinoline degradation occured within $12 \mathrm{~h}$ at $\mathrm{pH} 7$ and at a temperature of $37^{\circ} \mathrm{C}$. The degradation kinetics of quinoline by strain Bacillus sp. LH-1 followed Haldane's model and indicated that the strain isolated in this study could be used for degradation of heterocyclic nitrogenous compounds in industrial wastewater.
\end{abstract}

Keywords: Bacillus sp. LH-1, biodegradation kinetics, induction condition, quinoline

\section{Introduction}

Heterocyclic nitrogenous compounds are of significant concern from an environmental perspective because of their toxic and carcinogenic properties, lethal effect on the natural biogenic environment, and severe odor. Given these threats, it is critical to prevent the discharge of these substances into the environment [1-3].

*e-mail: liuyongjun@xauat.edu.cn
Quinoline and its derivatives are typical heterocyclic nitrogenous compounds, widely present in coal tar, oil shale and petroleum.

Quinoline is a popular industrial raw material and acts as a solvent for dyes, paints, fungicides and wood-treatment chemicals [4], and is also used as a substrate in the production of medicines such as fluoroquinolone antibiotics. A significant anthropogenic source of environmental pollution by quinoline and their derivatives is coal processing. The global manufacture of coal tar in cooking plants reaches a value $15 \times 10^{6}$ tons per year, whereas the content of quinoline is $0.2-0.3 \%$. 
Moreover, quinoline can be found in creosote, which is obtained during coal processing. Concentrations of quinolone in wastewater generated during shale oil production reach 2-50 $\mathrm{mgL}^{-1}$. Concentrations of quinoline are about $10 \mathrm{mg} / \mathrm{L}$ in coking wastewater and $40-80 \mathrm{mg} / \mathrm{L}$ in semi-coking wastewater [5-6].

With a lone pair of electrons on the $\mathrm{N}$-atoms in the ring system, quinolines and other N-heterocyclic compounds are more polar than homocyclic analogues. This makes these industrial wastes significantly more water soluble than other substances. Quinolines have been documented as toxic pollutants due to their carcinogenic and mutagenic properties [7].

Many treatment methods are used to degrade quinoline. Physical or chemical treatments are generally supplemental treatments because of their high operating cost and generation of secondary pollutants [8]. The main biological treatments include conventional activated sludge, or $\mathrm{A}^{2} / \mathrm{O}$ and $\mathrm{SBR}$ processes [911]. However, the refraction and toxicity of quinoline and its derivatives in wastewater adversely affect the performance of biological treatment systems and result in failure to meet current effluent discharge standards.

In recent years, research has focused on bioaugmentation technology using special strains to enhance organic pollutant removal from wastewater [12-13]. Bacteria play an important role in the energy cycle and material cycle of the natural ecosystem. The practical application also shows that it is feasible to deal with recalcitrant substances by using microbial metabolism through biological enhancement.

Over the past decade, studies have found several bacteria with the excellent capability to degrade quinoline. These include Arthrobacter sp. [14], Microbacterium sp. [15], Burkholderia sp. [16], Rhodococcus sp., Desulfobacterium sp. [17], Comamonas sp. [18], Achromobacter sp. [19] and Pseudomonas sp, which is the dominant genus among quinoline-degrading bacteria. Previous studies have comprehensively focused on its biodegradation pathway, relevant enzymes, and degradation genes [20-23]. Many bacteria can degrade quinoline, but their efficiencies are either low or have poor tolerance. Use of technical means to activate the strains improves its degradation ability for specific pollutants and provides a richer source of superior strains and more channels for the bioaugmentation of wastewater treatment systems.

The goal of this study was to identify new quinoline-degrading bacterial strains, explore their degradation properties, and assess the impact of acclimation conditions on the quinoline biodegradation rate. Degradation kinetics were also studied to describe the quinoline degradation process. The study identifies valuable sources of bacteria for the microbial degradation of quinoline and provides useful information about heterocyclic nitrogenous compounds and their relationship to degrading bacteria. These results will provide insights to support bioaugmentation in industrial wastewater treatment or the implementation of in situ bioremediation at contaminated sites.

\section{Experimental}

\section{Reagents and the Culture Medium Used in this Study}

Quinoline at purity levels greater than 99\% was purchased from Aladdin. Methanol at purity levels greater than $99.9 \%$ was purchased from Fisher for high-performance liquid chromatography (HCLP) analysis. All other chemicals used were of analytical grade, purchased from local suppliers. Activated sludge samples were collected from the Xi'an Beishiqiao Wastewater Treatment Facility in Xi'an, China.

A Luria-Bertani (LB) medium was used to enrich the bacteria. A mineral salt medium (MSM) was used to isolate a quinoline-degrading strain containing the following ingredients (per liter): $\mathrm{Na}_{2} \mathrm{HPO}_{4}$ $4.26 \mathrm{~g}, \quad \mathrm{KH}_{2} \mathrm{PO}_{4} 2.65 \mathrm{~g}, \mathrm{MgSO}_{4} \cdot 7 \mathrm{H}_{2} \mathrm{O} \quad 0.2 \mathrm{~g}$, $\mathrm{CaCl}_{2} 0.02 \mathrm{~g}$, and $1 \mathrm{ml}$ of a trace element solution. The trace element solution contained (per liter): $\mathrm{MnSO}_{4} \cdot 4 \mathrm{H}_{2} \mathrm{O} 0.2 \mathrm{~g}, \mathrm{ZnCl}_{2} 0.01 \mathrm{~g}, \mathrm{H}_{3} \mathrm{BO}_{3} 0.07 \mathrm{~g}$, $\mathrm{CuCl}_{2} \cdot 2 \mathrm{H}_{2} \mathrm{O} \quad 0.005 \mathrm{~g}, \quad \mathrm{Na}_{2} \mathrm{MoO}_{4} \cdot 2 \mathrm{H}_{2} \mathrm{O} \quad 0.04 \mathrm{~g}$, $\mathrm{FeSO}_{4} \cdot 7 \mathrm{H}_{2} \mathrm{O} 1.5 \mathrm{~g}$, and $\mathrm{CoCl}_{2} \cdot 6 \mathrm{H}_{2} \mathrm{O} 0.004 \mathrm{~g}$ [16].

The solid medium included $1.8 \%$ agar. Different concentrations of quinoline were filtered through a 0.22 um pore size filter and then added to the sterile MSM as the sole carbon, nitrogen, and energy source.

\section{Domestication and Isolation of Superior Strains for Quinoline Degradation}

Activated sludge samples were inoculated and cultivated for approximately $24 \mathrm{~h}$ in a rotary shaker at $37^{\circ} \mathrm{C}$ with $180 \mathrm{rpm}$ rotating speed. All microbes in the supernatant were enriched in the $\mathrm{LB}$ medium at $37^{\circ} \mathrm{C}$ in a rotary shaker for $24 \mathrm{~h}$. Afterwards, the culture was inoculated in the MSM to acclimate the quinolinedegrading microbes. The cultures were acclimated to increasing concentrations of quinoline through successive transfers. The initial concentration was $50 \mathrm{mgL}^{-1}$, which was gradually increased by incremental amounts of $50 \mathrm{mgL}^{-1}$ to the highest concentration of $500 \mathrm{mgL}^{-1}$. Next, quinoline-degrading bacteria colonies were purified using plate-streaking technology on an MSM plate containing $500 \mathrm{mgL}^{-1}$ of quinoline.

\section{Identifying Quinoline-Degrading Bacteria}

The genomic DNA of LH-1 was extracted using the method described by Liu et al. [24]. 16s rDNA fragments of the screened dominant strains for quinoline degradation were amplified with the primers 27F (5'-AGAGTTTGATCMTGGCTCAG-3') and 1492R (5'-CGGYTACCTTGTTACGACTT-3'). PCR reaction, 
BLAST program and the phylogenetic tree construction were performed according to Liu et al. [25].

\section{Inducing Conditions of the Dominant Strain for Quinoline Biodegradation}

Bacteria suspensions $\left(\mathrm{OD}_{600}=1.5 \pm 0.2\right)$ were added using the same dose as the MSM containing quinoline, at $100 \mathrm{mgL}^{-1}, 200 \mathrm{mgL}^{-1}$, and $300 \mathrm{mgL}^{-1}$. Then, bacteria were collected at regular intervals to create new bacterial suspensions to degrade quinoline at a concentration of $300 \mathrm{mgL}^{-1}$. The effects of acclimation time and initial acclimation concentration on the microbial degradation rate were investigated.

The same process was repeated using the MSM with quinoline at $200 \mathrm{mgL}^{-1}$; in this test, glucose, acetic acid, methanol, pyridine, phenol, phthalic acid, citric acid, sucrose and lactose were added respectively at $100 \mathrm{mgL}^{-1}$ concentrations. The effects of these additional carbon sources on microbial acclimation time and degradation rate were also investigated.

\section{Tolerance and Influencing Factors of Quinoline Biodegradation}

(1) Quinoline tolerance test. The quinolinedegrading bacteria LH-1 were inoculated in a sterile LB medium containing $300 \mathrm{mgL}^{-1}$ quinoline and cultivated overnight at $37^{\circ} \mathrm{C}$. After that, the cells were centrifuged and washed three times using an inorganic salt solution $(\mathrm{pH}=7)$ and then suspended in the inorganic salt medium. Cell density was brought to $\mathrm{OD}_{600}=1.5 \pm 0.2$. The cells were added based on the same dosing quantities as with the MSM culture medium, at quinoline concentrations of approximately $100 \mathrm{mgL}^{-1}, 200 \mathrm{mgL}^{-1}, 300 \mathrm{mgL}^{-1}, 400 \mathrm{mgL}^{-1}, 500 \mathrm{mgL}^{-1}$, $600 \mathrm{mgL}^{-1}, 700 \mathrm{mgL}^{-1}$, and $800 \mathrm{mgL}^{-1}$. Making the initial $\mathrm{OD}_{600}=0.15 \pm 0.02$, interval sampling was used to analyze the residual quinoline concentration and bacterial growth. The initial $\mathrm{pH}$ value of the medium was adjusted to 7.0 using $\mathrm{HCl}$ and $\mathrm{NaOH}$ before autoclaving. The growth media and all solutions were autoclaved for $25 \mathrm{~min}$ at $121^{\circ} \mathrm{C}$ and $105 \mathrm{~Pa}$. All cultivation was conducted at $37^{\circ} \mathrm{C}$ in a rotary shaker at a speed of 180 rpm.

(2) Influencing factors of quinoline biodegradation. The microbial strain was inoculated in $50 \mathrm{~mL}$ of the $\mathrm{LB}$ medium and then grown at $37^{\circ} \mathrm{C}$ in a rotary shaker at $180 \mathrm{rpm}$. After $24 \mathrm{~h}$ of incubation, the cell cultures were washed and transferred to fresh sterilization MSM medium containing a concentration of $200 \mathrm{mgL}^{-1}$ quinoline for the acclimation stage. Cells were harvested during the late exponential growth phase, at the $120 \pm 15 \mathrm{~h}$ point. The cells were then washed and prepared into the bacteria suspension $\left(\mathrm{OD}_{600}=1.5 \pm 0.2\right)$ as inoculums.

Using quinoline as the sole carbon and energy source, quinoline biodegradation was studied at $\mathrm{pH}$ levels of $4,5,6,7,8$, and 9 , which are the $\mathrm{pH}$ of an inorganic salt solution without quinoline. The initial inoculant doses were $0.04,0.067,0.086,0.117$, and $0.165 \mathrm{gL}^{-1}$. The tested temperature levels were $25^{\circ} \mathrm{C}$, $30^{\circ} \mathrm{C}, 37^{\circ} \mathrm{C}$, and $42^{\circ} \mathrm{C}$. During these experiments, samples were run at each level for each variable with the other variables fixed, and samples were periodically removed from the medium and analyzed for cell density and residual substrate concentrations.

The degradation rate of quinoline is expressed as:

$$
K=\frac{S_{0}-S_{t}}{T_{t}-T_{0}}
$$

...where $\mathrm{S}_{\mathrm{t}}$ and $\mathrm{S}_{0}\left(\mathrm{mgL}^{-1}\right)$ are the substrate concentrations of $T_{t}$ time and the initial substrate concentrations of $T_{0}$ time, respectively.

\section{Kinetics Analysis of Quinoline Gegradation}

The LH-1 strain was cultured in LB liquid medium and acclimated to the late exponential growth phase with $200 \mathrm{mg} \mathrm{L}^{-1}$ quinoline. Using the method above, bacterial cells were harvested and inoculated into $100 \mathrm{ml} \mathrm{MSM}$, containing approximately $100-700 \mathrm{mgL}^{-1}$ quinoline. The beginning value of the $\mathrm{OD}_{600}$ was approximately $0.15 \pm 0.02$. Incubations were grown at $37^{\circ} \mathrm{C}$ with shaking at $180 \mathrm{rpm}$. Cell density and residual quinoline concentrations were determined over a $45 \mathrm{~h}$ period.

The substrate inhibited cell growth. As such, Haldane's equation was selected for the kinetics elements of the study [26-27].

\section{Analysis Methods of Quinoline and Cell Density}

Samples were collected from the culture at different time points to measure the optical density of cells and the quinoline concentrations, which were determined using HPLC (Thermo, U3000) equipped with a C18 column (Thermo, $100 \times 2.1 \mathrm{~mm}$ inner diameter, $1.7 \mathrm{~m}$ particle size). Samples were centrifuged at $8000 \mathrm{rpm}$ for $10 \mathrm{~min}$. The supernatant for each sample was collected and filtered through a $0.22 \mu \mathrm{m}$ pore size filter for analysis. The mobilephase, consisting of a methanol and water mixture $(65: 35, \mathrm{v} / \mathrm{v})$, was introduced to the column at a flow rate of $0.2 \mathrm{mLmin}^{-1}$. Quinoline was detected at a $275 \mathrm{~nm}$ wavelength; its retention time was $3.65 \mathrm{~min}$. The $\mathrm{pH}$ was measured using a $\mathrm{pH}$ meter (PHS-3C, Lei Ci).

The cell density of the microbial culture was estimated using a UV spectrophotometer (TU1901, Persee) by measuring its absorbance (OD) at a wavelength of $600 \mathrm{~nm}$. All tests were done in triplicate.

\section{GC/MS Analysis of Metabolites}

Possible metabolites were analyzed with GC/MS (Agilent $7890 \mathrm{GC} / 7000 \mathrm{~A}, \mathrm{DB}-5 \mathrm{MS}$ narrow bore column, 
$30 \mathrm{~m} \times 0.25 \mathrm{~mm} \times 0.25 \mu \mathrm{m})$. Reaction products were extracted with ethyl acetate and dried over anhydrous $\mathrm{Na}_{2} \mathrm{SO}_{4}$. Helium was used as the carrier gas with a flow rate of $1 \mathrm{ml} \cdot \mathrm{min}^{-1}$, injector volume of $1 \mu \mathrm{L}$ and injector temp of $280^{\circ} \mathrm{C}$. The oven temperature was programmed at $40^{\circ} \mathrm{C}$ for $2 \mathrm{~min}$, followed by a linear increase of $5^{\circ} \mathrm{C} / \mathrm{min}$ to $200^{\circ} \mathrm{C}$, holding at $200^{\circ} \mathrm{C}$ for $5 \mathrm{~min}$, followed by a linear increase of $7^{\circ} \mathrm{C} / \mathrm{min}$ to $280^{\circ} \mathrm{C}$ and holding at $280^{\circ} \mathrm{C}$ for $5 \mathrm{~min}$. MS analysis was performed at electron energy of $70 \mathrm{eV}$ and ion source temp of $230^{\circ} \mathrm{C}$. The structures of metabolites were confirmed from the fragmentation patterns of the mass spectra, through comparison with those predicted for known compounds.

\section{Results and Discussion}

Screening and Identification of the Dominant Strain for Quinoline Degradation

Three bacterial colonies capable of degrading quinoline were isolated from the activated sludge of a municipal wastewater treatment plant using the streak plate method. The 16S rRNA gene fragments of strains with the ability to degrade quinoline were named LH-1, LH-B and LH-X and were deposited in the GenBank data library with the accession numbers KX442614, MF062572 and MF062570, respectively. Among them, strain LH-1 had the best degradation effect and stability when quinoline was provided as the sole source of carbon, nitrogen, and energy, so the follow-up study is aimed at LH-1.

Strain LH-1 formed smooth, convex, opaque, and wet colonies. The 2-3 $\mathrm{mm}$ diameter circular colonies were milky white and slightly yellow and could be easily scraped off nutrient agar plates after being incubated at $37^{\circ} \mathrm{C}$ for $1-2$ days. Each individual bacterium grew aerobically and was gram-positive, short, and rodshaped. 16srRNA gene fragments of strain LH-1 were obtained by PCR amplification, and then submitted for sequencing. The BLAST search of the sequences indicated that strain LH-1 was closely related to the species in genus of Bacillus, and also exhibited the highest similarity (99.93\%) to Bacillus sp. and thus we tentatively classified strain LH-1 as Bacillus sp. LH-1 (KX442614; Fig. 1). Some researchers have found that Bacillus sp. can degrade phenol, benzo[a]pyrene [28], pyridine [29], Polyethylene [30] and waxy crude oil [31]. This suggests that Bacillus sp. could have a great potential application in the biodegradation of organic contaminants and remediation of water and soil.

\section{Tolerance Test of the Quinoline Concentrations for the Dominant Strain}

The effect of the strain Bacillus sp. LH-1 in degrading quinoline was studied over an initial $100-800 \mathrm{mgL}^{-1}$ quinoline concentration (Fig. 2a). Results showed that the strains could grow at quinoline concentrations ranging from $100-700 \mathrm{mgL}^{-1}$. The quinoline removal rate reached $93.43 \%, 95.05 \%, 98.59 \%, 96.72 \%, 98.19 \%$, $98.33 \%$ and $98.19 \%$ at concentrations of $100 \mathrm{mgL}^{-1}$, $200 \mathrm{mgL}^{-1}, 300 \mathrm{mgL}^{-1}, 400 \mathrm{mgL}^{-1}, 500 \mathrm{mgL}^{-1}, 600 \mathrm{mgL}^{-1}$, and $700 \mathrm{mgL}^{-1}$, respectively. However, even after $420 \mathrm{~h}$, the strain Bacillus sp. LH-1 could not degrade quinoline at a concentration of $800 \mathrm{mgL}^{-1}$, manifesting a strong substrate inhibition.

However, there was a long lag time before the cells began to accommodate the high quinoline concentration and start to degrade it. The lag time increased and the strain Bacillus sp. LH-1 cell biomass became antiblastic as the initial quinoline concentration increased. At a $100 \mathrm{mgL}^{-1}$ quinoline concentration, the lag time was approximately $90 \mathrm{~h}$; at a $700 \mathrm{mgL}^{-1}$ quinoline concentration, the lag time increased to $350 \mathrm{~h}$. After the inhibitory stage, degradation began at 20-35 h. Both cell growth and quinoline degradation occurred in this time frame. In the first $50 \mathrm{~h}$, cell concentrations significantly

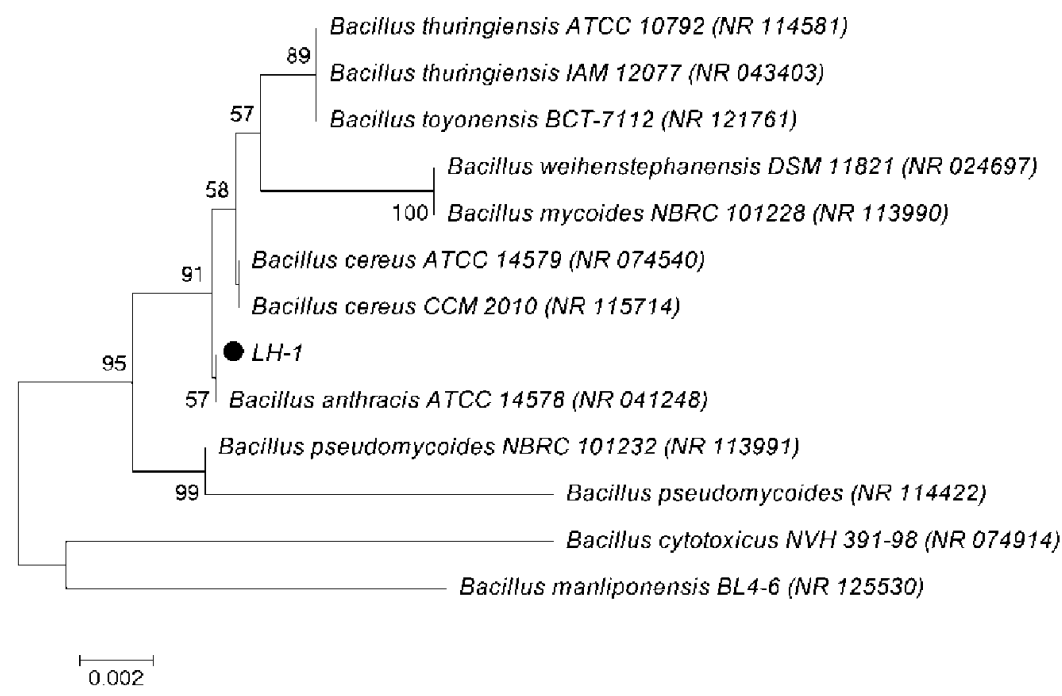

Fig. 1. Phylogenetic tree based on 16S rDNA sequences of strains named LH-1 and its related species. 

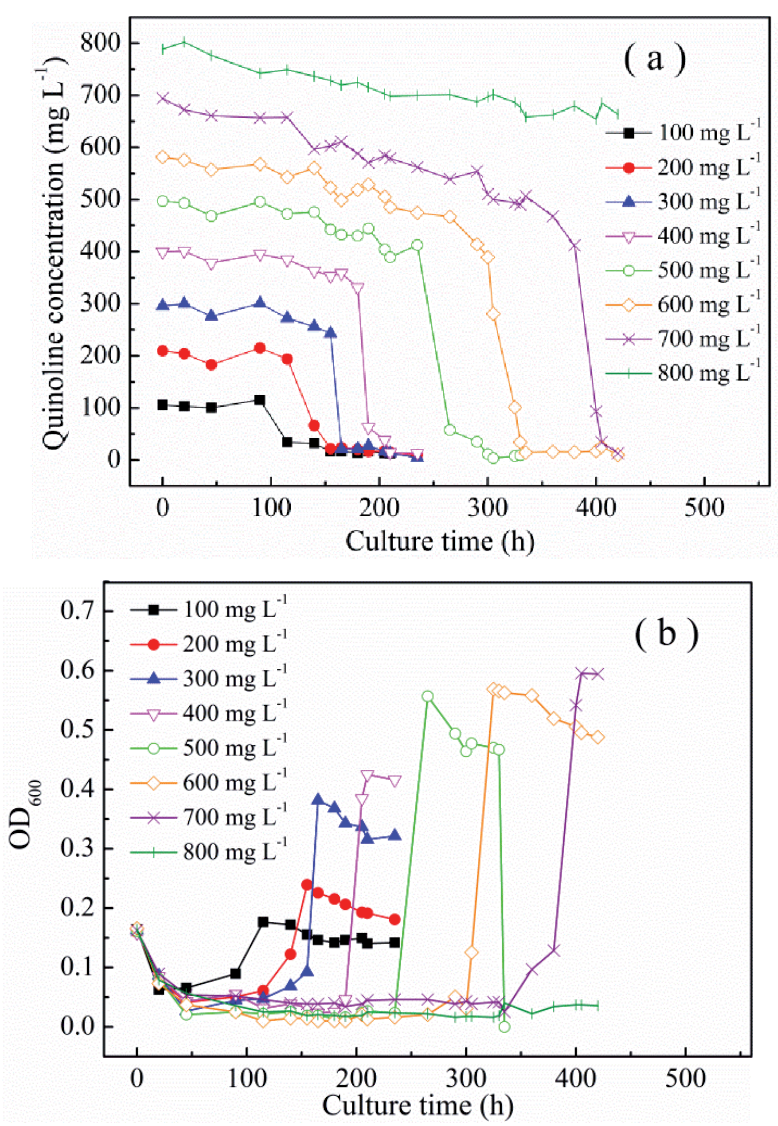

Fig. 2. Influence of initial quinoline concentration on a) quinoline degradation and b) biomass variation of the strain Bacillus sp. $\mathrm{LH}-1$ at $\mathrm{pH} 7$ and $37^{\circ} \mathrm{C}$.

A: quinolone $\mathrm{B}$ : uinoline+glucose $\mathrm{C}$ : quinoline+acetic acid $\mathrm{D}$ : quinoline + methanol $\mathrm{E}$ : quinoline+pyridine

F: quinoline+phenol G: quinoline+phthalic acid

$\mathrm{H}$ : quinoline+citric acid I: quinoline+sucrose

$\mathrm{J}$ : quinoline+lactose

declined due to the toxic effects of quinoline (Fig. 2b). However, after the inhibition period, the bacteria appear to have adapted to the quinoline toxicity, and then started to use it as a nutrient.

In the $150-300 \mathrm{mgL}^{-1}$ range, quinoline can be used by most quinoline-degrading bacterial strains. Only selected bacterial strains, even with immobilized cells, can degrade more than $300 \mathrm{mgL}^{-1}$ of quinoline [22]. For example, in one study, Pseudomonas sp. strain BW003 degraded 192-911 $\mathrm{mgL}^{-1}$ of quinoline within 3-8 h [21]. In this study, Bacillus sp. strain LH-1 grew at concentrations of $100-700 \mathrm{mgL}^{-1}$ quinoline, with a degradation rate exceeding 95\%. However, LB enrichment caused long-term inhibition of the strains. As such, this study examined how acclimation conditions quantitatively affect quinoline degradation.

\section{Inducing Conditions of Quinoline Degradation for Strain Bacillus sp. LH-1}

To improve quinoline degradation efficiency, lower concentrations were used to acclimate strains.
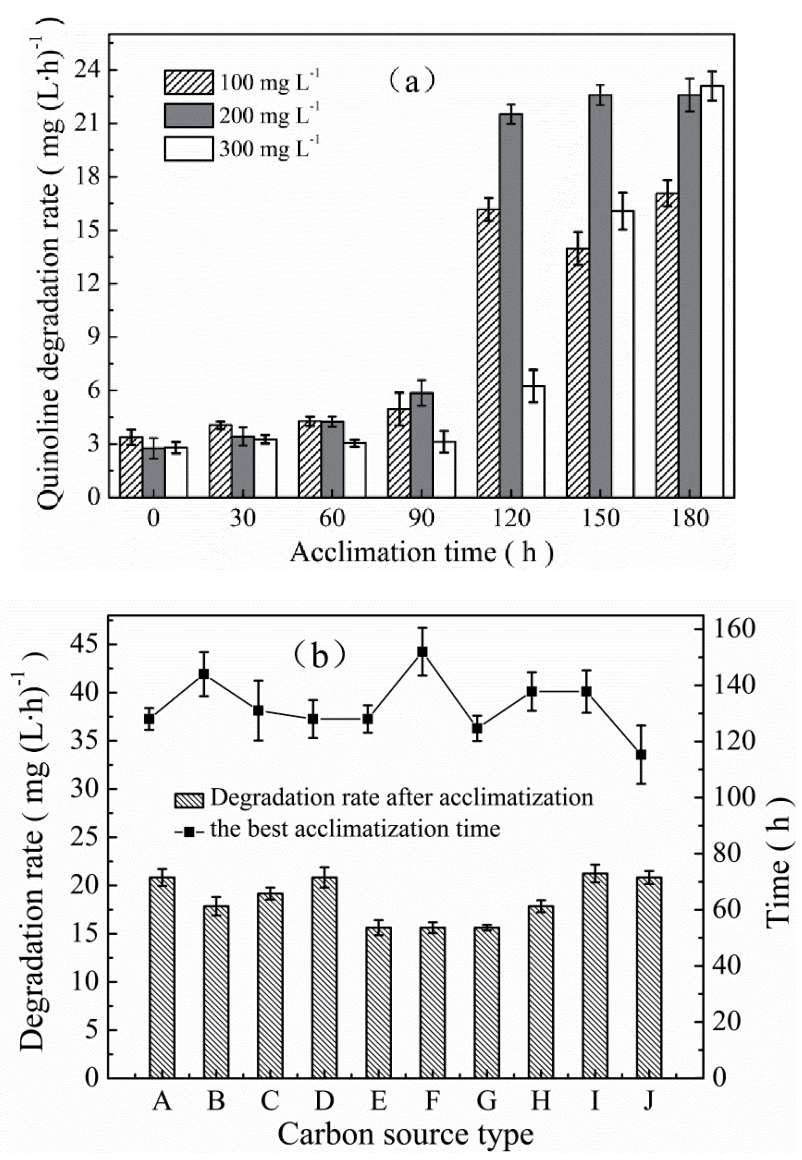

Fig. 3. Inducing conditions of quinoline degradation for strain Bacillus sp. $\mathrm{LH}-1$ at $\mathrm{pH} 7$ and $37^{\circ} \mathrm{C}$ : a) activation of the acclimation time and the quinoline concentration on strain Bacillus sp. LH-1 for the quinoline biodegradation and b) activation of different carbon sources on strain Bacillus sp. LH-1 for quinoline biodegradation; error bars represent standard deviation of triplicate tests.

Samples collected at different points in the acclimation process were analyzed to quantitatively determine how acclimation conditions impact the ability of strain Bacillus sp.LH-1 to degrade quinoline.

The initial quinoline acclimation concentration and acclimation time significantly affected the microbial degradation rate (Fig. 3a). Strains were acclimated for $120 \mathrm{~h}$ at initial quinoline concentrations of $100 \mathrm{mgL}^{-1}$ and $200 \mathrm{mgL}^{-1}$, the largest degradation rates were $16.167 \mathrm{mg}\left(\mathrm{L} \cdot \mathrm{h}^{-1}\right.$ and $21.508 \mathrm{mg}\left(\mathrm{L}^{-} \mathrm{h}\right)^{-1}$. It took $180 \mathrm{~h}$ to achieve a maximum degradation rate of $23.095 \mathrm{mg}\left(\mathrm{L}^{\circ} \mathrm{h}\right)^{-1}$ at an acclimation concentration of $300 \mathrm{mg} \mathrm{L}^{-1}$.

An acclimation concentration of $200 \mathrm{mgL}^{-1}$ positively affected quinoline degradation. The bacteria synthesized an inducible enzyme in the process of degrading quinoline. Acclimation may allow bacteria to adapt to the environment in advance, and may promote the generation of this inducible enzyme. Hence, acclimation in small concentrations of quinoline may improve the bacteria's ability to degrade high concentrations of quinoline. The quinoline degradation rate of the strain Bacillus sp. LH-1 increased as acclimation time 
increased. The average degradation rate of the strain Bacillus sp.LH-1 strain was only $2.030 \mathrm{mg}\left(\mathrm{L}^{\circ} \mathrm{h}\right)^{-1}$ without an acclimation period. The rate increased significantly, reaching $21.508 \mathrm{mg}\left(\mathrm{L}^{\circ} \mathrm{h}\right)^{-1}$ after a $120 \mathrm{~h}$ acclimation period $\left(200 \mathrm{mgL}^{-1}\right)$. This rate was 10.6 times more than before acclimation in a system containing $300 \mathrm{mgL}^{-1}$ quinoline.

This experiment also investigated how introducing other organic sources affected the quinoline degradation rate when acclimated at a quinoline concentration of $200 \mathrm{mgL}^{-1}$ (Fig. 3b). Adding a carbon source to support quinoline acclimation played no significant role, as the best acclimation time remained more than $120 \mathrm{~h}$.

Previous studies have shown that bacteria require long-term domestication to degrade organic matter. This is particularly true when degrading refractory organic matter [5, 32]. The same applies to degrading quinoline; without domestication, microbial metabolism efficiency is low and unstable for specific pollutants. Many scholars have cultivated bacteria in an inorganic salt solution to the logarithmic phase containing target pollutants, which was also the initial bacterial acclimation process [19, 27]. However, few researchers have described the acclimation characteristics in detail, resulting in only a vague understanding of the quantitative characteristics of acclimation conditions during quinoline biodegradation.

The best acclimation period for the strain Bacillus sp.LH-1 was $120 \pm 15$ h. This outcome occurs during the logarithmic phase of the MSM system containing $200 \mathrm{mgL}^{-1}$ quinoline, regardless of whether there is a supplementary carbon source. The appropriate acclimation concentration and timeframe benefitted acclimation efficiency; the result was a two-fold effect with only half the effort.

The follow-up dynamic experiment will assess the acclimation of $200 \mathrm{mgL}^{-1}$ quinoline in an inorganic salt medium; bacteria are cleaned and prepared in a suspension that is part of the corresponding reaction system. Research was also done to assess the influence of temperature and $\mathrm{pH}$ on quinoline degradation, and quinoline degradation kinetics after acclimation.

\section{Influencing Factors of Quinoline Biodegradation}

Fig. 4a) shows how initial inoculant dosage affects quinoline degradation by the strain Bacillus sp. LH-1 at $37^{\circ} \mathrm{C}$ with a quinoline concentration of $300 \mathrm{mgL}^{-1}$ at $\mathrm{pH}$ 7. The degradation process sped up slightly at an increased inoculant dosage, but results were generally similar when the initial inoculant dosages were $0.086 \mathrm{gL}^{-1}, 0.117 \mathrm{gL}^{-1}$, and $0.165 \mathrm{gL}^{-1}$. At the same time, Fig. 4b) shows that bacteria biomass had an inhibitive effect due to quinoline toxicity in the early phase. Biomass experienced some stagnation and slow growth, but there does not appear to have been significant biomass reduction, which shows that after acclimation, bacteria adapts better to the quinoline environment and the inhibition period is greatly reduced. When the added bacteria levels were greater than $0.086 \mathrm{gL}^{-1}$, the bacterial competition for the substrate slightly changed the overall degradation efficiency, but the final biomass was maintained at a higher level. Considering both bacteria growth and quinoline degradation, $0.086 \mathrm{~g}$ $\mathrm{L}^{-1}$ was the ideal amount of bacteria when $10 \%(\mathrm{v} / \mathrm{v})$ of the cell suspension was inoculated to the media and the initial $\mathrm{OD}_{600}$ was approximately 0.15 .

Experiments to assess optimal $\mathrm{pH}$ levels for quinoline degradation were performed at $37^{\circ} \mathrm{C}$ with a quinoline concentration of $300 \mathrm{mgL}^{-1}$ (Fig. 4c). The best initial $\mathrm{pH}$ range was 5-7, indicating that Bacillus sp. LH-1 strain cell growth and quinoline degradation were higher in slightly acid media. Quinoline degradation by Bacillus sp. LH-1 and biomass growth were inhibited in an alkaline environment at $\mathrm{pH}$ values of 8 and 9; the lag period was approximately 30 hours (Fig. 4d), which may be because an environment that is too alkaline can damage the cells' surface potential and enzyme activity, suppress quinoline degradation, and even crack cells and destroy cellular structures. A strongly acidic environment at a $\mathrm{pH}$ of 4 is also unfavorable to bacterial growth.

$\mathrm{pH}$ of solution may also affect the presence of the substrate quinoline, which exists as a positively charged protonated form under acidic conditions and in the form of neutral molecules under alkaline conditions. Normally, neutral molecules are more susceptible to bacterial attack and degradation, but because the addition of quinoline will increase the $\mathrm{pH}$ of the MSM, at the same time quinoline degradation will release ammonia nitrogen in the process, so the $\mathrm{pH}$ increases during the whole degradation process.

Therefore, a meta-acid environment rapidly becomes more neutral, resulting in a neutral culture as the reaction progresses. The final result shows that MSM has the highest efficiency of quinoline degradation under conditions of neutral partial acidity. This encourages bacteria growth and increased enzyme activities. There can be enzyme disintegration or substrate dissociation at the active center of the group if the system contains too much acid and alkali, which affects enzyme and substrate combinations, enzyme denatured inactivation and reduced substrate use.

Fig. 4e) shows the effect of temperature on quinoline biodegradation after the strain Bacillus sp. LH-1 acclimation. At a temperature range of $20-42^{\circ} \mathrm{C}$, quinoline degraded well in aerobic conditions. Quinoline degradation rate was highest at $37^{\circ} \mathrm{C}$, decreasing in descending order at $30^{\circ} \mathrm{C}, 42^{\circ} \mathrm{C}$, and $25^{\circ} \mathrm{C}$. Biomass growth adapted to quinoline degradation (Fig. 4f). The results indicate that strain Bacillus sp.LH-1 is a mesophilic type of bacteria, with an optimal temperature of $30-37^{\circ} \mathrm{C}$. This result is consistent with other research, which concluded that mesophilic bacteria had advantages in degrading quinolone $[4,7]$.

In this study, the best $\mathrm{pH}$ and temperature for cell growth and quinoline degradation were close to 

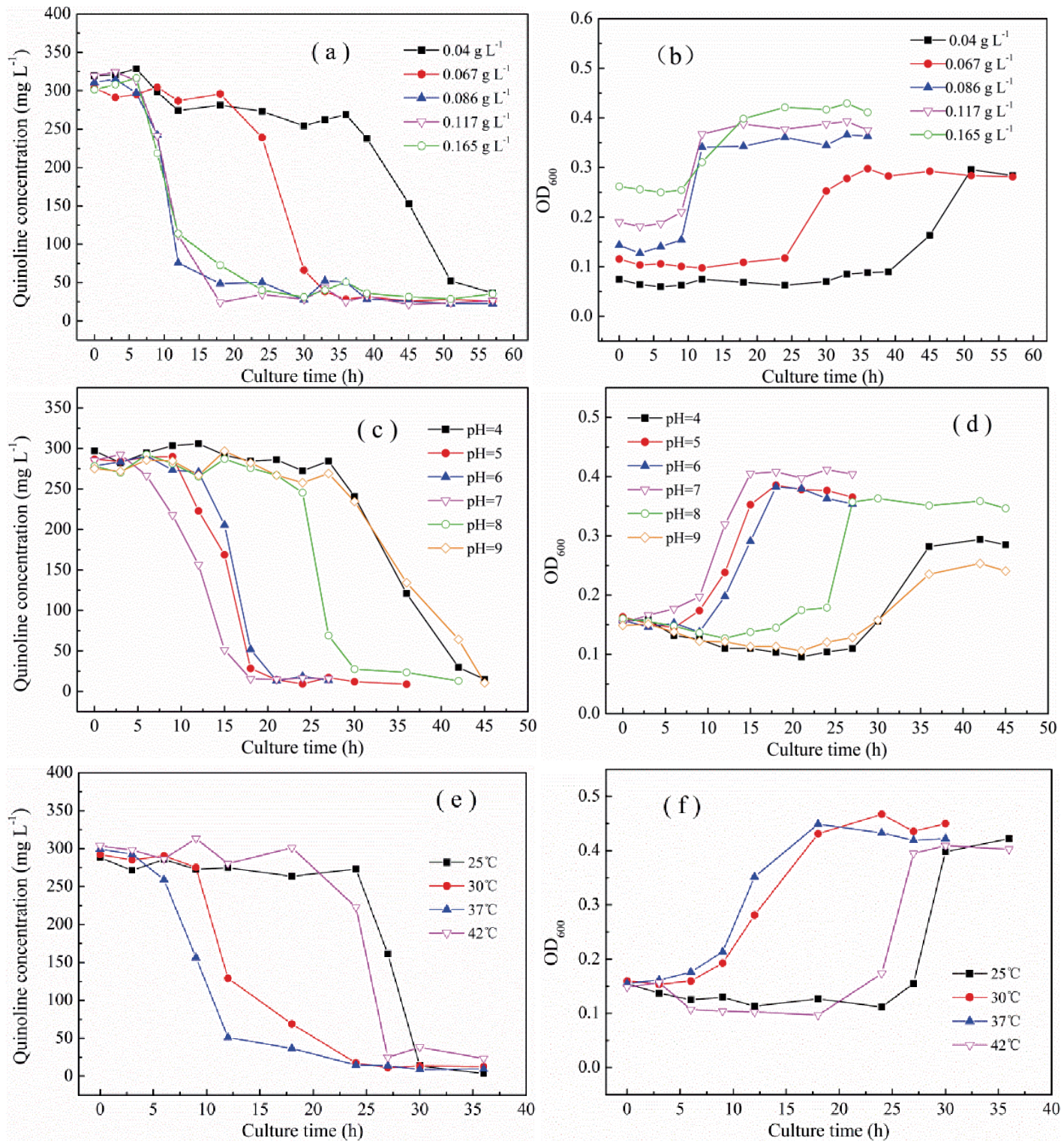

Fig. 4. Influence of different factors on quinoline degradation and biomass variation of the strain Bacillus sp. LH-1: a) influence of the inoculation dosage on quinoline degradation; b) influence of the inoculation dosage on the biomass of Bacillus sp. LH-1; c) influence of $\mathrm{pH}$ on quinoline degradation; d) influence of $\mathrm{pH}$ on biomass of Bacillus sp. LH-1; e) influence of temperature on quinoline degradation; and f) influence of temperature on biomass of Bacillus sp. LH-1.
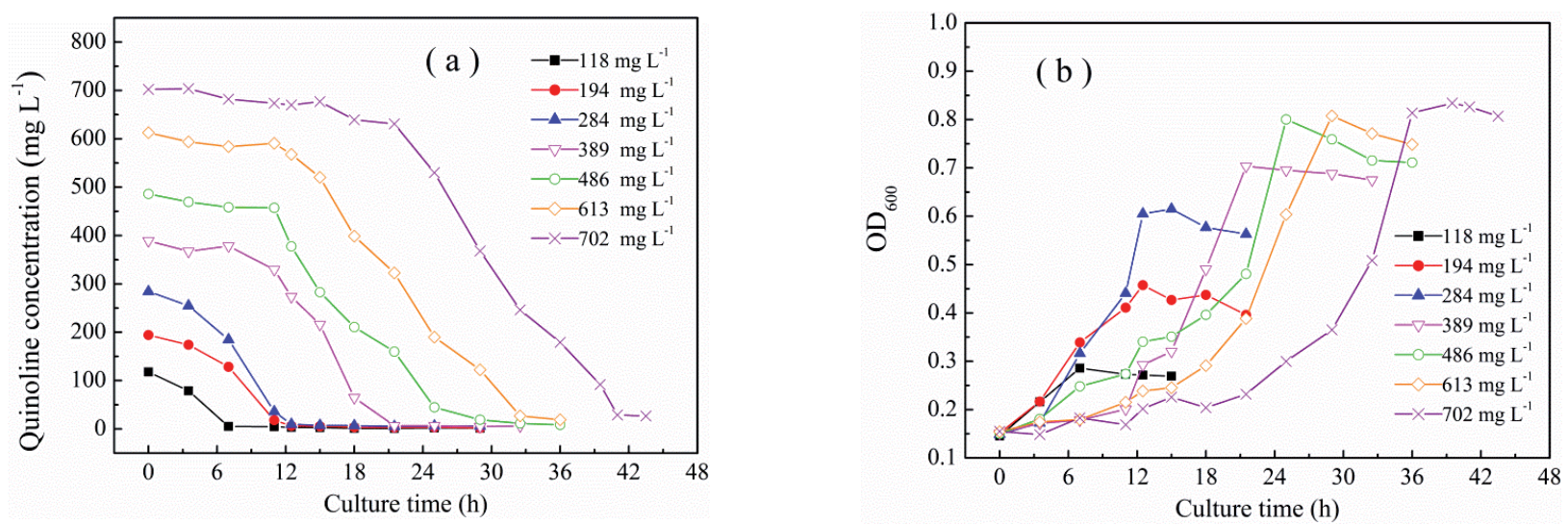

Fig. 5. Quinoline degradation rate a) and biomass variation of the strain Bacillus sp. LH-1 b) under the conditions of different initial quinoline concentrations after the strain was activated. 

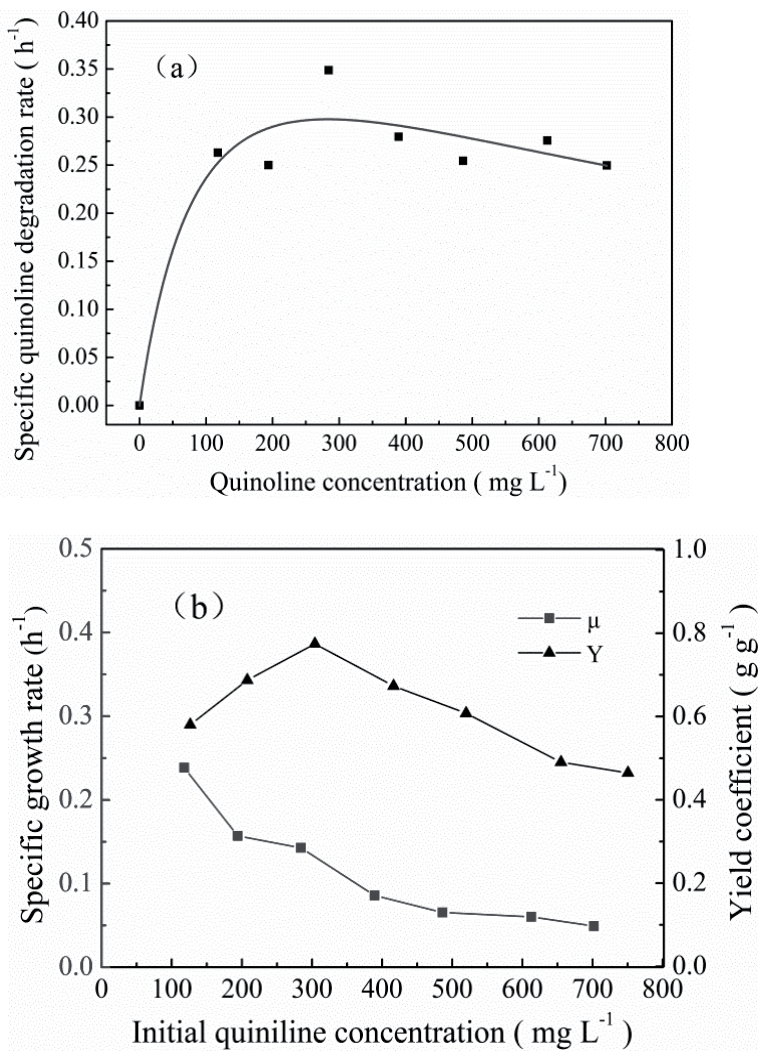

Fig. 6. Specific growth rate, yield coefficient and specific growth kinetics of the strain Bacillus sp. LH-1 under the conditions of different initial quinoline concentrations: a) experimental and predicted specific growth kinetics of the strain and b) specific growth rate and yield coefficient of the strain.

real-world conditions. This suggests that quinoline pollution can be eliminated by applying degrading bacteria as part of bioaugmentation treatments. The strain Bacillus sp. LH-1 growth was optimized in a solution with a $\mathrm{pH}$ of 7 and at $37^{\circ} \mathrm{C}$. In these conditions, more than $96.55 \%$ of quinoline at an initial inoculant pure strain dose of $0.087 \mathrm{gL}^{-1}$ was degraded within $12 \mathrm{~h}$.

\section{Kinetic Characteristics of Quinoline Biodegradation by Bacillus sp. LH-1}

Quinoline degradation dynamics were further investigated after LH-1 acclimation. More than $95 \%$ of quinoline was removed at concentrations of $100-300 \mathrm{mg} / \mathrm{L}$ within $12 \mathrm{~h}$ of inoculation without a lag phase (Fig. 5). In contrast, there was a lag phase when the quinoline concentration increased from 400 to $700 \mathrm{mgL}^{-1}$. A high initial quinoline concentration resulted in the longest degradation time; however, the quinoline removal rate was not related to the initial concentration, and remained between 95.62-98.29\%.

Haldane's mathematical model was used to generate kinetic parameters of $q_{\max }=0.529 \mathrm{~h}^{-1}$, $K_{S}=10.058 \mathrm{mgL}^{-1}$, and $K_{i}=727.733 \mathrm{mgL}^{-1}$ (correlation coefficient $\left.\mathrm{R}^{2}=0.9015\right)$. Fig. 6a) shows the contrast between the theoretical and experimental values. The regression curve fit the experimental data very well. Based on the differential equation, the Bacillus sp. LH-1 strain degrades the quinoline best at a concentration of $283.007 \mathrm{mgL}^{-1}$. At lower quinoline concentrations, the quinoline degradation rate is lower due to the lack of good carbon sources of energy and limited cell growth. When the quinoline concentration exceeds $283.007 \mathrm{mgL}^{-1}$, the high quinoline concentration inhibits assimilation and substrate degradation.

As the initial substrate concentration increased, the specific growth rate decreased; this may be the result of intense substrate inhibition (Fig. 6b). The maximum specific growth rate was $0.2384 \mathrm{~h}^{-1}$, which occurred at a very low substrate concentration. The higher substrate

a)
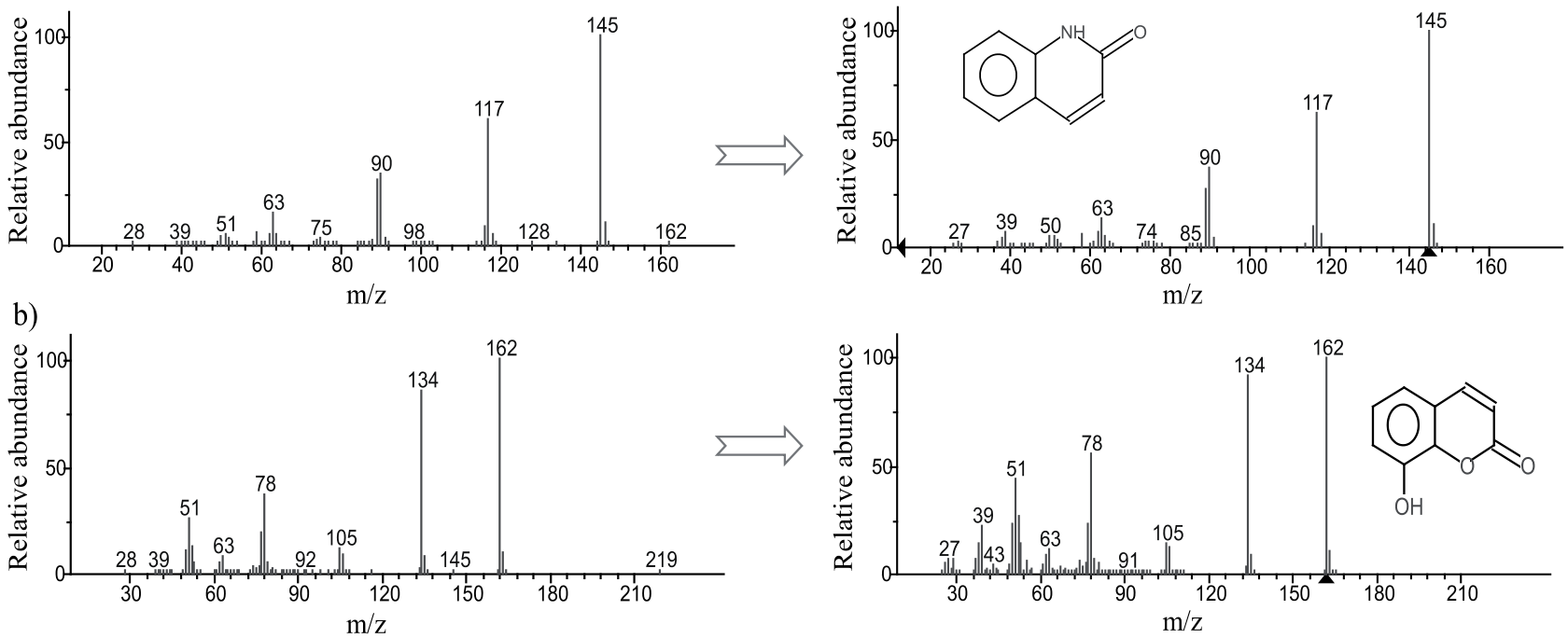

Fig. 7. Mass spectra of quinolone metabolites by Bacillus sp. LH-1. a) and b): comparisons of mass spectrum data of 2-hydroxyquinoline and 8-hydrocumarinwith authentic standards. 
concentration led to a stronger inhibitory response. Bacteria yields in the rapid biodegradation phase first increased and then decreased as the initial quinoline concentration increased. The maximum yield was 0.774 when the quinoline concentration was $300 \mathrm{mgL}^{-1}$. This result was consistent with Haldane equation's estimate of the best quinoline concentration. At a larger Y value, more biomass is obtained from the degradation unit mass matrix, with highly efficient bacteria.

In this study, quinoline degradation by Bacillus sp. created a pink compound. This is consistent with other studies that have tested quinoline biodegradation using different microbes, and indicates that quinoline biodegradation by different bacteria may produce colorful intermediates [4]. 2-hydroxyquinoline and 8-hydrocumarinwere were detected by GC/MS during the quinoline biodegradation (Fig. 7). Preliminary speculation is that the Bacillus sp. biodegradable quinoline via the 8-hydroxycoumarin pathway. Quinoline biodegradation intermediates and metabolic pathways using the strain Bacillus sp. LH-1 will be further analyzed both qualitatively and quantitatively in the future. These results broaden the ways in which Bacillus sp. may be used in the field of environmental protection research, especially with respect to biodegrading heterocyclic nitrogenous compounds.

\section{Conclusions}

A new bacterial strain identified as Bacillus sp. LH-1 was isolated and which can use quinoline as its sole carbon, nitrogen, and energy source. The strain grew well in quinoline concentrations of $100-700 \mathrm{mgL}^{-1}$. When the strain was triggered under the conditions of $200 \mathrm{mgL}^{-1}$ quinoline concentration and kept for $120 \mathrm{~h}$, the degradation rate of quinoline significantly increased from $2.030 \mathrm{mg}\left(\mathrm{L}^{\circ} \mathrm{h}\right)^{-1}$ to $21.508 \mathrm{mg}\left(\mathrm{L}^{\circ} \mathrm{h}\right)^{-1}$, and the other organic carbon sources did not appear to promote or inhibit quinoline degradation efficiency. After the strain was activated, more than $96.55 \%$ of the quinoline (initial quinoline concentration was $300 \mathrm{mgL}^{-1}$ ) were degraded within $12 \mathrm{~h}$, and the biodegradation kinetics were consistent with Haldane's model (the kinetic parameters were: $q_{\max }=0.529 \mathrm{~h}^{-1}, K_{S}=110.058 \mathrm{mgL}^{-1}, K_{i}=727.733 \mathrm{mgL}^{-1}$ and $\left.\mathrm{R}^{2}=0.9015\right)$. Bacillus sp. can be used in the degradation process of refractory organic compounds, and the development of the bacillus bacterial agent could provide an effective source and technical support for biological enhancement of wastewater treatment.

\section{Acknowledgements}

This study was supported by the Science and Technology Industrialization Project of Shaanxi Education Department under grant No. 15JF021, the Scientific Research Program Funded by Shaanxi
Provincial Education Department under grant No. 17JK0868, and the Project of Science and Technology Benefit Plan under grant No. 2012GS610203.

\section{Conflict of Interest}

The authors declare no conflict of interest.

\section{References}

1. ZHAO C., ZHANG Y., LI X-B., WEN D-H., TANG X-Y. Biodegradation of carbazole by the seven Pseudomonas sp. strains and their denitrification potential,Journal of hazardousmaterials, 190 (1-3), 253, 2011.

2. HU W-J., NIU C-G., WANG Y., ZENG G-M., ZHEN W. Nitrogenous heterocyclic compounds degradation in the microbial fuel cells, Process Safety and Environmental Protection, 89 (2), 133,2011.

3. JOSHI D-R., ZHANG Y., ZHANG H., GAO Y-X., YANG M. Characteristics of microbial community functional structure of a biological coking wastewater treatment system, Journal of Environmental Sciences, 63, 105, 2018.

4. TUO B-H., YAN J-B., FAN B-A., YANG Z-H., LIU $\mathrm{J}-\mathrm{Z}$. Biodegradation characteristics and bioaugmentation potential of a novel quinoline-degrading strain of Bacillus sp. isolated from petroleum-contaminated soil,Bioresource technology, 107, 55,2012.

5. FELCZAK A., ZAWADZKA K., LISOWSKA K. Efficient biodegradation of quinolone Factors determining the process - International Biodeterioration \& Biodegradation, 96, 127,2014.

6. FETZNER S., TSHISUAKA B., LINGENS F., KAPPL R., HUTTERMANN J. Bacterial degradation of quinoline and derivatives e pathways and their biocatalysts. Angewandte Chemie International Edition. 37, 576, 1998.

7. WANG L., LI Y-M., DUAN J-Y. Biodegradation of 2-methylquinoline by Enterobacter aerogenes TJ-D isolated from activated sludge,Journal of Environmental Sciences, 25 (7), 1310,2013.

8. LIANG Y., LI S., LI B. Removal of Toxic Organic Pollutants from Coke Plant Wastewater by UV-Fenton, Journal of Residuals Science \& Technology, 13, S143, 2016.

9. ZOU S-S., ZHANG B-B., YAN N., ZHANG C-Y., ZHANG Y-M., RITTMANN B-E. Competition for molecular oxygen and electron donor between phenol and quinoline during their simultaneous biodegradation, Process Biochemistry, 70, 136, 2018.

10. LIU X-D., CHEN Y., ZHANG X., JIANG X-B., WU S-J., SHEN J-Y., SUN X-Y., LI J-S., LU L., WANG L-J. Aerobic granulation strategy for bioaugmentation of a sequencing batch reactor (SBR) treating high strength pyridine wastewater, Journal of hazardous materials, 295, 153, 2015.

11. BAI Y-H., SUN Q-H., ZHAO C., WEN D-H.,TANG $\mathrm{X}-\mathrm{Y}$. Bioaugmentation treatment for coking wastewater containing pyridine and quinoline in a sequencing batch reactor. Applied microbiology and biotechnology, 87 (5),1943, 2010.

12. ZHU X-B., TIAN J., CHEN L. Phenol degradation by isolated bacterialstrains: kinetics study and applicationin 
coking wastewater treatment,Journal of Chemical Technology \& Biotechnology, 87, 123, 2012.

13. BAI Y-H., SUN Q-H., SUN R-H., WEN D-H., TANG $\mathrm{X}-\mathrm{Y}$. Bioaugmentation and adsorption treatment of coking wastewater containing pyridine and quinoline using zeolite-biological aerated filters.Environmental science \& technology, 45 (5), 1940, 2011.

14. HUND H-K., DE B-A., LINGENS F. Microbial metabolism of quinoline and related compounds. VI. Degradation of quinaldine by Arthrobacter sp., Biological chemistry Hoppe-Seyler, 371 (10), 1005, 1990.

15. SCHMIDT M., RÖGER P., LINGENS F. Microbial metabolism of quinoline and related compounds. XI. Degradation of quinoline-4-carboxylic acid by Microbacterium sp. H2, Agrobacterium sp. 1B and Pimelobacter simplex 4B and 5B.Biological chemistry Hoppe-Seyler, 372 (11), 1015, 1991.

16. WANG J-L., WU W-Z., ZHAO X. Microbial Degradation of Quinoline: Kinetics Study With Burkholderiapicekttii. China, Biomedical and Environmental Sciences, 17 (1), 21, 2004.

17. JOHANSEN S-S., LICHT D., ARVIN E., MOSBEK H., HANSEN A-B. Metabolic pathways of quinoline, indole and their methylated analogs by Desulfobacterium indolicum (DSM 3383), Applied microbiology and biotechnology, 47 (3), 292, 1997.

18. CUI M-C., CHEN F-Z., FU J-M., SHENG G-Y., SUNG-P. Microbial Metabolism of Quinoline by Comamonas sp.,World Journal of Microbiology and Biotechnology, 20 (6), 539, 2004.

19. ZHAO G-B., CHEN S-Y., REN Y., WEI C-H. Interaction and biodegradation evaluate of $\mathrm{m}$-cresol and quinoline in co-exist system. International Biodeterioration \& Biodegradation, 86, 252, 2014.

20. ZHAO C., WEN D-H., ZHAN G Y., ZHAN G.J., TANG $\mathrm{X}-\mathrm{Y}$. xperimental and mathematical methodology on the optimization of bacterial consortium for the simultaneous degradation of three nitrogen heterocyclic compounds, Environmental science \& technology, 46 (11), 6205, 2012.

21. SUN Q-H., BAI Y-H., ZHAO C., XIAO Y-N., WEN D-H., TANG X-Y. Aerobic biodegradation characteristics and metabolic products of quinoline by a Pseudomonas strain, Bioresource technology, 100 (21), 5030, 2009.

22. QIAO L., WANG J-L. Biodegradation characteristics of quinoline by Pseudomonas putida, Bioresource technology, 101 (19), 7683,2010.
23. CARL B., AMOLD A., HAUER B., FETZNER S. Sequence and transcription alanalysis of a gene cluster of Pseudomonas putida 86 involved in quinoline degradation. Gene, 331, 177, 2004.

24. LIU Y., TANW-H., WUX-Q., WUZ-X., YU G-L., LI R-H. First report of microcystin production in Microcystis smithii Komarek and Anagnostidis (Cyanobacteria) from a water bloom in Eastern China. Journal of Environmental Sciences, 23 (1), 102, 2011.

25. LIU Y-J., GAO M., ZHANG A-N., LIU Z. Strengthen effects of dominant strains on aerobic digestion and stabilization of the residual sludge, Bioresource technology, 235, 202, 2017.

26. LIU Y-J., KUSCHK P., ZHANG A-N., WANG X-C. Characterisation of phenol degradation by sp. XA05 and sp. FG03. Chemistry and Ecology, 25 (2), 107, 2009.

27. YAO H-Y., REN Y., DENG X-Q., WEI, C-H. Dual substrates biodegradation kinetics of $\mathrm{m}$-cresol and pyridine by Lysinibacillus cresolivorans. Journal of hazardous materials, 186 (2-3), 1136, 2011.

28. U D., LI P-J., FRANK S., XIONG X-Z. Biodegradation of benzo[a]pyrene in soil by Mucor sp. SF06 and Bacillus sp. SB02 co-immobilized on vermiculite. Journal of Environmental Sciences, 18 (6), 1204,2006.

29. CHANDRA R., YADAV S., BHARAGAVA R-N. Biodegradation of pyridine raffinate by two bacterial cocultures of Bacilluscereus (DQ435020) and Alcaligenes faecalis (DQ435021).World Journal of Microbiology and Biotechnology, 26 (4), 685, 2009.

30. ZHANG J-F., ZHANG C-N., ZHU Y-P., LI J-L., LI X-T. Biodegradation of seven phthalate esters by Bacillus mojavensis B1811, International Biodeterioration \& Biodegradation, 132, 200, 2018.

31. SAKTHIPRIYA N., DOBLEM., SANGWA J. Kinetic and thermodynamic behavior of the biodegradation of waxy crude oil using Bacillus subtilis, Journal of Petroleum Science and Engineering, 160, 412, 2018.

32. CHEN S., CHANG C., DENG Y., AN S., DONG Y-H., ZHOU J., HU M., ZHONG G., ZHANG L-H. Fenpropathrin Biodegradation Pathway in Bacillus sp. DG-02 and Its Potential for Bioremediation of PyrethroidContaminated Soils, Journal of Agricultural \& Food Chemistry, 62 (10), 2147, 2014. 